\title{
Non-Syndromic Orofacial Cleft Malformations in Jeddah, Saudi Arabia
}

\author{
Sabah S. Moshref ${ }^{1}$, FRCS, Yasir S. Jamal' ${ }^{2}$, FRCS(I), FICS, Mahmoud Fakiha ${ }^{4}$, MD, DESC, \\ Basim A. Awan ${ }^{1}$, FRCS(C), Fayza Alsiny ${ }^{3}$, CABP, Fatma Alzhrani ${ }^{3}$, CABP, \\ Hossam Ammar ${ }^{1}$, CAB / PL S EBPRS, Abdullah Bamashmos ${ }^{1}$, MBBCh, MSc Surgery, \\ and Abeer Baamer ${ }^{1}$, MBBCh
}

${ }^{1}$ Department of Surgery, Division of Plastic Surgery, Faculty of Medicine, King Abdulaziz University

${ }^{2}$ Department of Surgery, Division of Pediatric Surgery, Faculty of Medicine, University of Jeddah

${ }^{3}$ Department of Pediatrics, Faculty of Medicine, King Abdulaziz University, Jeddah, Saudi Arabia

${ }^{4}$ Department of Surgery, Division of Plastic Surgery, Faculty of Medicine, University of Jeddah, Jeddah, Saudi Arabia

\section{Correspondence}

Prof. Sabah S. Moshref

P.O. Box 80215, Jeddah 21589, Saudi Arabia

e.M: dr.sabahmoshref@gmail.com

Submission: 26 April 2017

Accepted: $\quad 05$ June 2017

\section{Citation}

Moshref SS, Jamal YS, Fakiha M, Awan BA, Alsiny F, Alzhrani F, Ammar H, Bamashmos A, Baamer A. Non-syndromic orofacial cleft malformations in Jeddah, Saudi Arabia. JKAU Med Sci 2017; 24

(3): 1-11. DOl: 10.4197/Med. 24.3.1

\begin{abstract}
This retrospective, hospital based study aims to investigate demographic and clinical characteristics of pediatric patients with orofacial cleft in Jeddah, Saudi Arabia from 2005 to 2015. Hospital surgical records from three main sources, King Abdulaziz University Hospital, Bagedo and Dr. Erfan Hospital and Dr. Soliman Fakeeh Hospital were used to identify all consecutive surgical cases with orofacial cleft referred to these hospitals. Information about age, sex, cleft types, site, maternal risk factors, associated pediatrics problems and treatment were recorded. The most common type was cleft lip and palate $(40.15 \%)$, then isolated cleft palate (35.61\%) and isolated cleft lip (24.24\%). Maternal risk factor was mostly smoking (4.55\%); pediatrics complication was mostly speech abnormalities and dental problems (75.00\%); post-operative complication was mostly speech abnormalities (72.54\%). Our study reveals that epidemiologic aspects of orofacial cleft in Jeddah are very similar to other Caucasian populations with a predominance of cleft lip, unilateral left side. Routine screening such as chest x-ray and ruling out hearing and speech problems as well as genetic counseling and karyotyping may be necessary in these patients. Better understanding of demographic and clinical characteristics may help guide clinical care as well as contribute to an improved understanding of pathogenesis.
\end{abstract}

\section{Keywords}

Demographic characteristics; Maternal risk factors; Nonsyndromatic orofacial clefts; Pediatrics problems 


\section{Introduction}

rofacial clefting (OFC) involves structures around the oral cavity which can extend on to the facial structures resulting in oral, facial and craniofacial deformity. The main categories are isolated cleft palate $(C P)$ and cleft lip with or without cleft palate (CL/P). Orofacial clefts are common congenital malformations, second only to clubfoot in frequency of occurrence ${ }^{[1]}$. The epidemiology of $\mathrm{CP}$ and $\mathrm{CL} / \mathrm{P}$ are distinct, with an estimated prevalence of 6.35 CP per 10,000 live births and an estimated prevalence of $10.63 \mathrm{CL} / \mathrm{P}$ per 10,000 live births ${ }^{[2]}$. Prevalence of $\mathrm{CP}$ is consistent among races, while $C L / P$ varies, with the highest prevalence in Native Americans (3.6 in 1000 live births) and Asian Americans (2.1 in 1000 live births) and the lowest in African Americans (0.41 in 1000 live births) ${ }^{[3]}$. Prevalence also varies with geographic location, maternal age, teratogen exposure, and socioeconomic status ${ }^{[4]}$.

Although not a major cause of mortality, OFC does cause considerable morbidity to affected children and imposes a substantial financial risk for families with a concomitant social burden. Affected children have a range of functional as well as aesthetic problems. These include feeding difficulties at birth due to problems with oral seal, swallowing and nasal regurgitation, hearing difficulties due to abnormalities in the palatal musculature, and speech difficulties due to nasal escape and articulation problems. These cleft defects can be surgically repaired in childhood, but residual deformity due to scarring and abnormal facial development results in continuing functional and psychosocial problems ${ }^{[4]}$.

The causes of OFC are largely unknown, although it has long been assumed that both genetic and environmental factors are important. There is evidence that clefting is seen more frequently among Asians (1 to 2 in 1000) and less frequently among African Americans $(0.5 \text { to } 1 \text { in } 1000)^{[5]}$. Maternal prenatal exposures investigated include smoking ${ }^{[6]}$, alcohol consumption ${ }^{[7]}$, and vitamin-deficient diet ${ }^{[8]}$. Genetic contributions are also being increasingly recognized with the most established contributor being variants in the IRF6 gene ${ }^{[9]}$. Despite the recent progress in identifying environmental and genetic risk factors for orofacial clefts, major gaps in knowledge remain, possibly due to differences in the populations studied and study design.

The aim of this retrospective, hospital based study was to investigate the demographic and clinical characteristics of pediatric patients with nonsyndromatic OFC. These observations may help to improve our understanding of factors that play a role in the occurrence of OFC, aid in the development of public health prevention efforts, and provide information useful to clinicians caring for patients with OFC.

\section{Material and Methods}

In this retrospective, hospital based study records of all cases of oral cleft reconstruction admitted to King Abdulaziz University, Bagedo and Dr. Erfan Hospital and Dr. Soliman Fakeeh Hospital (tertiary referral centers) in Jeddah, Saudi Arabia during the 11-year period between January 2005 and December 2015 were reviewed. All surgical treatments of clefts were performed in these hospitals. The register of congenital abnormalities among live births was examined. The source of data for the present study was mainly from information recorded in the case notes. Other sources, such as photographic records and surgical operating lists, were used to supplement the information obtained from case notes. Original data collection included nationality, sex, age at referral time, type, side and site of cleft, family history of orofacial clefts, maternal risk factors at the time of the child's birth, pediatrics problems, age and numbers of repaired operations, pre-operative status, treatment, postoperative complications as well as length of hospital stay. Most patients were referred by other physicians or centers in different age groups for secondary repair of clefts or other stages of cleft reconstruction. Therefore, we recorded only the age at first operation for $\mathrm{CL}$ or $\mathrm{CP}$. The initial physical examination was performed by a pediatrician. A simple descriptive classification was used to record cleft type, as follows: cleft lip (unilateral/ bilateral); cleft lip and palate (unilateral/bilateral); and cleft palate. Patients with clefts associated with recognized single-gene disorders, chromosome abnormalities, holoprosencephaly, or amniotic band sequence or those with a cleft lip and palate associated with syndromes or cases with isolated lip pit, isolated cleft gum, or bifid uvula or submucous clefts or those 
records lacking necessary information were excluded from the study.

\section{Statistical Analysis}

The data obtained were statistically analyzed by using IBM SPSS Statistics for Windows, Version 20 (IBM Corp., Armonk, NY USA). Data was expressed as number and percentage. Chi-square was used to determine the statistical significance between the data. A $P<0.05$ was accepted as statistically significant.

\section{Results}

The most common type was cleft lip and palate (CLP) $40.15 \%$, then isolated cleft palate (CP) $35.61 \%$, isolated cleft lip (CL) $24.24 \%$. The age of presentation of our patients was mostly 0-6 months $(n=516,97.93 \%)$ followed by $>6-12$ months $(n=12,2.27 \%$ ) with significant difference between them $(P=0.29)$, the same pattern of distribution were found in subgroups of patients. In all the patients, the number of male 318 $(60.23 \%)$ were insignificantly higher than female 210 (39.77\%); the unilateral side was significantly higher than bilateral sides [452 (85.61\%) vs. $76(14.39 \%)]$ and left side malformation was highest followed by right side then bilateral [294 (55.68\%) vs. $158(29.90 \%)$ and $76(14.39 \%)](P=0.0001$ for all), the same pattern of distribution were found in subgroups of patients. In all patients, there were insignificant difference between Saudi and non-Saudi [286 (54.17\%) vs. 242 (45.83\%), P $=0.944$ ] (Table 1).
When these malformations were classified by race and sex, the following data were obtained. Saudi boys showed a highest incidence of CLP ( $n=70,24.48 \%)$, followed by $C P(n=61,21.33 \%)$ and lastly $C L(n=42$, $14.69 \%)$. Saudi girls had a highest incidence of CLP ( $n=$ $44,15.38 \%)$, followed by CP $(n=40,13.99 \%)$ and lastly $\mathrm{CL}(\mathrm{n}=29,10.14 \%)$. Non-Saudi boys showed a highest incidence of CLP ( $n=60,24.80 \%)$, followed by CP $(n=$ $52,21.50 \%)$ and lastly $C L(n=33,13.64 \%)$. Non-Saudi girls had a highest incidence of CLP ( $n=38,15.70 \%)$, followed by CP ( $n=35,14.46 \%)$ and lastly $C L(n=24$, 9.92\%) (Table 2).

Of all clefting, maternal risk factors were mostly smoking ( $n=24,4.55 \%)$ followed by positive family history $(n=19,3.60 \%)$, maternal drugs intake $(n=11$, $2.08 \%)$, infection during pregnancy $(n=11,2.08 \%)$, diet deficiency $(n=8,1.52 \%)$, and maternal diseases $(n=6$, 1.14\%). In CL, CP and CLP groups, there were significant difference between groups in smoking $(1.56 \%, 7.45 \%$ and $3.77 \% ; P=0.038$ ). Of all clefting, pediatric problems were mostly dental problems $(n=396,75.00 \%)$ and speech abnormalities ( $n=396,75.00 \%)$, followed by feeding problems $(n=394,74.62 \%)$, anemia $(n=32$, $6.06 \%)$, otitis media ( $n=27,5.11 \%)$, recurrent chest infection ( $n=8,1.52 \%)$, hearing problems $(n=5$; $0.95 \%)$ and airway obstruction ( $n=4,0.76 \%)$. In $C L$, $\mathrm{CP}$ and CLP groups, there were significant difference between groups in dental problems $(P=0.0001)$; speech abnormalities $(P=0.0001)$; feeding problems ( $P$ $=0.0001)$; anemia $(P=0.0001)$; otitis media $(P=0.001)$; and recurrent chest infection $(P=0.050)$ (Table 3$)$.

Table 1. Demographic characteristics of all the studied subgroups.

\begin{tabular}{|c|c|c|c|c|c|}
\hline Variables & $\begin{array}{l}\text { Isolated Cleft Lip } \\
(n=128,24.24 \%)\end{array}$ & $\begin{array}{l}\text { Isolated Cleft Palate } \\
(\mathrm{n}=188,35.61 \%)\end{array}$ & $\begin{array}{l}\text { Cleft Lip and Cleft Palate } \\
\qquad(\mathrm{n}=212,40.15 \%)\end{array}$ & $\begin{array}{c}\text { Total } \\
(n=528,100 \%)\end{array}$ & $P$-value \\
\hline \multicolumn{5}{|l|}{ Age at Presentation } & \multirow[t]{3}{*}{0.029} \\
\hline $0-6$ months & $128(100.00 \%)$ & $185(98.40 \%)$ & $203(95.75 \%)$ & $516(97.73 \%)$ & \\
\hline$>6-12$ months & - & $3(1.60 \%)$ & $9(4.25 \%)$ & $12(2.27 \%)$ & \\
\hline \multicolumn{5}{|l|}{ Sex } & \multirow[t]{3}{*}{0.883} \\
\hline Male & $75(58.59 \%)$ & $113(60.11 \%)$ & $130(61.32 \%)$ & $318(60.23 \%)$ & \\
\hline Female & $53(41.41 \%)$ & $75(39.89 \%)$ & $82(38.68 \%)$ & $210(39.77 \%)$ & \\
\hline \multicolumn{5}{|l|}{ Nationality } & \multirow[t]{3}{*}{0.944} \\
\hline Saudi & $71(55.47 \%)$ & $101(53.72 \%)$ & $114(53.77 \%)$ & $286(54.17 \%)$ & \\
\hline Non-Saudi & $57(44.53 \%)$ & $87(46.28 \%)$ & $98(46.23 \%)$ & $242(45.83 \%)$ & \\
\hline \multicolumn{5}{|l|}{ Site } & \multirow[t]{3}{*}{0.0001} \\
\hline Unilateral & $122(95.31 \%)$ & $188(100.00 \%)-$ & $142(66.98 \%)$ & 452 (85.61\%) & \\
\hline Bilateral & $6(4.69 \%)$ & - & $70(33.02 \%)$ & $76(14.39 \%)$ & \\
\hline \multicolumn{5}{|l|}{ Side } & \multirow[t]{4}{*}{0.0001} \\
\hline Left & $92(71.88 \%)$ & $84(44.68 \%)$ & $118(55.66 \%)$ & $294(55.68 \%)$ & \\
\hline Right & $30(23.44 \%)$ & 104 (55.32\%) & $24(11.32 \%)$ & $158(29.92 \%)$ & \\
\hline Bilateral & $6(4.69 \%)$ & - & $70(33.02 \%)$ & $76(14.39 \%)$ & \\
\hline
\end{tabular}


Table 2. Cross tabulation of isolated cleft lip, isolated cleft palate and cleft lip and palate among race grouping by sex.

\begin{tabular}{|l|c|c|c|c|c|}
\hline \multirow{2}{*}{ Parameters } & \multicolumn{2}{|c|}{$\begin{array}{c}c \mid \\
\text { Naudi } \\
\end{array}$} & \multicolumn{2}{|c|}{$(\mathrm{n}=286,54.17 \%)$} & \multicolumn{2}{c|}{$\begin{array}{c}\text { Total Clefts } \\
(\mathrm{n}=242,45.83 \%)\end{array}$} \\
\cline { 2 - 6 } & Male & Female & Male & Female & \\
\hline Cleft Lip & $42(14.69 \%)$ & $29(10.14 \%)$ & $33(13.64 \%)$ & $24(9.92 \%)$ & $128(24.24 \%)$ \\
\hline Cleft Palate & $61(21.33 \%)$ & $40(13.99 \%)$ & $52(21.49 \%)$ & $35(14.46 \%)$ & $188(35.61 \%)$ \\
\hline Cleft Lip and Palate & $70(24.48 \%)$ & $44(15.38 \%)$ & $60(24.79 \%)$ & $38(15.70 \%)$ & $212(40.15 \%)$ \\
\hline Total Clefts & $173(60.49 \%)$ & $113(39.51 \%)$ & $145(59.92 \%)$ & $97(40.08 \%)$ & $528(100.00 \%)$ \\
\hline
\end{tabular}

Data are expressed as number (\% of the same group).

Table 3. Maternal risk factors and pediatrics problems in subgroups and all patients.

\begin{tabular}{|c|c|c|c|c|c|}
\hline Variables & $\begin{array}{l}\text { Isolated Cleft Lip } \\
(\mathrm{N}=128,24.24 \%)\end{array}$ & $\begin{array}{l}\text { Isolated Cleft Palate } \\
\quad(\mathrm{N}=188,35.61 \%)\end{array}$ & $\begin{array}{l}\text { Cleft Lip and Cleft Palate } \\
\quad(\mathrm{N}=212,40.15 \%)\end{array}$ & $P$-value & $\begin{array}{c}\text { Total } \\
(n=528,100 \%)\end{array}$ \\
\hline \multicolumn{6}{|l|}{ Maternal Risk Factors } \\
\hline Smoking & $2(1.56 \%)$ & $14(7.45 \%)$ & $8(3.77 \%)$ & 0.038 & $24(4.55 \%)$ \\
\hline Positive Family History & $3(2.34 \%)$ & $9(4.79 \%)$ & $7(3.30 \%)$ & 0.502 & $19(3.60 \%)$ \\
\hline Drugs & $1(0.78 \%)$ & $4(2.13 \%)$ & $6(2.83 \%)$ & 0.439 & $11(2.08 \%)$ \\
\hline Infection During Pregnancy & $1(0.78 \%)$ & $4(2.13 \%)$ & $6(2.83 \%)$ & 0.439 & $11(2.08 \%)$ \\
\hline Diet Deficiency & $10.78 \%)$ & $3(1.60 \%)$ & $4(1.89 \%)$ & 0.717 & $8(1.52 \%)$ \\
\hline Maternal Diseases & $1(0.78 .80 \%)$ & $1(0.53 \%)$ & $4(1.89 \%)$ & 0.403 & $6(1.14 \%)$ \\
\hline \multicolumn{6}{|l|}{ Pediatrics Problems } \\
\hline Dental Problems & - & $187(99.47 \%)$ & $209(98.58 \%)$ & 0.0001 & $396(75.00 \%)$ \\
\hline Speech Abnormalities & - & $188(100.00 \%)$ & $208(98.11 \%)$ & 0.0001 & $396(75.00 \%)$ \\
\hline Feeding Problems & - & $186(98.94 \%)$ & $208(98.11 \%)$ & 0.0001 & 394 (74.62\%) \\
\hline Anemia & - & $10(5.32 \%)$ & $22(10.38 \%)$ & 0.0001 & $32(6.06 \%)$ \\
\hline Otitis Media & - & $18(9.57 \%)$ & $9(4.25 \%)$ & 0.001 & $27(5.11 \%)$ \\
\hline Recurrent Chest Infections & - & $6(3.19 \%)$ & $2(0.94 \%)$ & 0.050 & $8(1.52 \%)$ \\
\hline Hearing Abnormalities & - & $3(1.60 \%)$ & $2(0.94 \%)$ & 0.356 & $5(0.95 \%)$ \\
\hline Airway Obstruction & - & $3(1.60 \%)$ & $1(0.47 \%)$ & 0.227 & $4(0.76 \%)$ \\
\hline
\end{tabular}

Data are expressed as number (\% of the same group). Significance between groups made using chi-square test.

Of all clefting, age of operative repair were mostly at 1-6 months $(n=297,56.25 \%)$ followed by $>6-12$ months ( $n=230,43.56 \%)$, then $>12$ months $(n=1$, $0.19 \%$ ); also in CL, CP and CLP subgroups, there were significant difference between groups regarding age of operative repair which were mostly at 1-6 months followed by $>6-12$ months, then $>12$ months $(P=$ 0.0001 ). Pre-operative infections were $1.70 \%$ in all patients; meanwhile in CP and CLP were $2.66 \%$ and $1.89 \%$ with insignificant difference between groups $(P=0.193)$. The numbers of operative repair in all patients were once $(58.52 \%)$, twice (38.83\%) and three times (2.65\%); in CL, CP and CLP subgroups, there were significant difference between groups regarding numbers of operation ( $P=0.0001)$. The palate width in all patients were mostly small (68.56\%) then normal (24.24\%), medium (7.20\%) with insignificant difference between groups $(P=0.0001)$ in $C L, C P$ and $C L P$ subgroups (Table 4).
Of all the patients, $98.86 \%$ administer antibiotics. In all patients, post-operative complications were mostly speech abnormalities followed by fever, otitis media, fistula, chest infection, bleeding, hearing problems, airway obstruction and wound complication $(72.54 \%$, $6.82 \%, 3.41 \%, 1.70 \%, 1.14 \%, 1.14 \%, 0.76 \%, 0.38 \%$, $0.38 \%$, respectively); in CL, CP and CLP subgroups, there were significant difference between groups regarding speech abnormalities, fistula, wound complication and hearing problems. The length of hospital stay in all patients were mostly $1-2$ days (24.24\%) and 3-4 days (75.76\%); in CL, CP and CLP subgroups, there were significant difference between groups regarding length of hospital stay $(P=0.0001)$ (Table 5$)$.

\section{Discussion}

The most common type was cleft lip and palate (CLP) $40.15 \%$, then isolated cleft palate (CP) $35.61 \%$, isolated 
Non-Syndromic Orofacial Cleft Malformations in Jeddah, Saudi Arabia S.S. Moshref et al.

Table 4. Operation related characteristics of all the studied subgroups.

\begin{tabular}{|c|c|c|c|c|c|}
\hline Variables & $\begin{array}{l}\text { Isolated Cleft Lip } \\
(\mathrm{N}=128,24.24 \%)\end{array}$ & $\begin{array}{l}\text { Isolated Cleft Palate } \\
(\mathrm{N}=188,35.61 \%)\end{array}$ & $\begin{array}{l}\text { Cleft Lip and Cleft Palate } \\
\quad(\mathrm{N}=212,40.15 \%)\end{array}$ & $P$-Value & $\begin{array}{c}\text { Total } \\
(\mathrm{N}=528,100 \%)\end{array}$ \\
\hline \multicolumn{6}{|l|}{ Age of Operative Repair } \\
\hline 1-6 months & $128(100.00 \%)$ & $6(3.19 \%)$ & $163(76.89 \%)$ & 0.0001 & $297(66.20 \%) 56.25 \%$ \\
\hline$>6-12$ months & - & $182(96.81 \%)$ & $48(22.64 \%)$ & & $230(43.56 \%)$ \\
\hline$>12$ months & - & - & $1(0.47 \%)$ & & $1(0.19 \%)$ \\
\hline Pre-Operative Infections & - & $5(2.66 \%)$ & $4(1.89 \%)$ & 0.193 & $9(1.70 \%)$ \\
\hline \multicolumn{6}{|l|}{ Pre-0perative Fitness } \\
\hline Healthy & $128(100.00 \%)$ & $187(99.47 \%)$ & $211(99.53 \%)$ & 0.722 & $526(99.62 \%)$ \\
\hline Not-Healthy & - & $1(0.53 \%)$ & $1(0.47 \%)$ & & $2(0.38 \%)$ \\
\hline \multicolumn{6}{|c|}{ Numbers of Operative Repair } \\
\hline 1 & 122 (95.31\%) & $187(99.47 \%)$ & - & 0.0001 & $309(58.52 \%)$ \\
\hline 2 & $6(4.69 \%)$ & $1(0.53 \%)$ & $198(93.40 \%)$ & & $205(38.83 \%)$ \\
\hline 3 & - & - & $14(6.60 \%)$ & & $14(2.65 \%)$ \\
\hline \multicolumn{6}{|l|}{ Palate Width } \\
\hline Normal & $128(100.00 \%)$ & - & - & 0.0001 & $128(24.24 \%)$ \\
\hline Small & - & $162(86.17 \%)$ & $200(94.34 \%)$ & & $362(68.56 \%)$ \\
\hline Medium & - & $26(13.83 \%)$ & $12(5.66 \%)$ & & $38(7.20 \%)$ \\
\hline
\end{tabular}

Data are expressed as number (\% of the same group). Significance between groups made using chi-square test.

Table 5. Post-operative status and complications of all the studied subgroups.

\begin{tabular}{|c|c|c|c|c|c|}
\hline Variables & $\begin{array}{l}\text { Isolated Cleft Lip } \\
(n=128,24.24 \%)\end{array}$ & $\begin{array}{l}\text { Isolated Cleft Palate } \\
\qquad(\mathrm{n}=188,35.61 \%)\end{array}$ & $\begin{array}{l}\text { Cleft Lip and Cleft Palate } \\
\quad(n=212,40.15 \%)\end{array}$ & $\begin{array}{c}\text { Total } \\
(\mathrm{n}=528,100 \%)\end{array}$ & $P$-value \\
\hline \multicolumn{6}{|l|}{ Treatment } \\
\hline Antibiotics & $128(100.0 \%)$ & $187(99.47 \%)$ & 207 (97.64\%) & 522 (98.86\%) & 0.086 \\
\hline \multicolumn{6}{|c|}{ Postoperative Complications } \\
\hline Speech Abnormalities & $1(0.78 \%)$ & 182 (96.81\%) & $200(94.34 \%)$ & $383(72.54 \%)$ & 0.0001 \\
\hline Fever & - & $19(10.11 \%)$ & $17(8.02 \%)$ & $36(6.82 \%)$ & 0.001 \\
\hline Otitis Media & $1(0.78 \%)$ & $7(3.72 \%)$ & $10(4.72 \%)$ & $18(3.41 \%)$ & 0.146 \\
\hline Fistula & - & $1(0.53 \%)$ & $8(3.77 \%)$ & $9(1.70 \%)$ & 0.010 \\
\hline Chest Infection & - & $4(2.13 \%)$ & $2(0.94 \%)$ & $6(1.14 \%)$ & 0.203 \\
\hline Bleeding & - & $3(1.60 \%)$ & $3(1.42 \%)$ & $6(1.14 \%)$ & 0.373 \\
\hline Hearing Problems & - & $2(1.06 \%)$ & $2(0.94 \%)$ & $4(0.76 \%)$ & 0.520 \\
\hline Airway Obstruction & - & $1(0.53 \%)$ & $1(0.47 \%)$ & $2(0.38 \%)$ & 0.722 \\
\hline Wound Complications & $1(0.78 \%)$ & $1(0.53 \%)$ & - & $2(0.38 \%)$ & 0.479 \\
\hline \multicolumn{5}{|c|}{ Length of Post-Operative Hospital Stay } & \multirow{3}{*}{0.0001} \\
\hline $1-2$ days & $128(100.00 \%)$ & - & - & $128(24.24 \%)$ & \\
\hline 3-4 days & - & $188(100.00 \%)$ & $212(100.00 \%)$ & $400(75.76 \%)$ & \\
\hline
\end{tabular}

Data are expressed as number (\% of the same group). Significance between groups made using chi-square test.

cleft lip (CL) 24.24\%. Other studies ${ }^{[1,5,10]}$ reported similarly that the most common type of oral cleft is CLP. In a study conducted in Kuwait, al-Bustan et al. ${ }^{[1]}$ reported that of the 121 patients, 34 (28.1\%) had CP, 30 (24.8\%) had CL and 57 (47.1\%) had CLP. In a study published on a Caucasian population in California from 1983-1992, Croen et al. ${ }^{[12]}$ reported that the prevalence of CLP was $50 \%, C L 25 \%$, and CP $25 \%$. McLeod et al. ${ }^{[13]}$ found the overall birth prevalence of clefts to be 1.23/ 1000 live births per year; they collected data for Bolivia for the years 1995 through 2001. They reported that $\mathrm{CL}$ was more common than CP. Reddy et al. ${ }^{[14]}$ reported in the state of Andhra Pradesh, South India in 2001 that the prevalence of CLP was $64 \%, C L 33 \%$, and CP $3 \%$. The Yazdee et al. ${ }^{[15]}$ study in Iran reported 177 cases with OFC, of them 92 persons (52\%) had CLP, 40 persons (22.6\%) had isolated CP, 45 (25.4\%) had CL. A study on an African population done in Nigeria showed prevalence to be CL 49\%, CLP 32\% and CP 19\% ${ }^{[16]}$. The reason for the low percentage of $\mathrm{CP}$ could be due to 
under reporting of the problem. Clefts of the palate alone are the most likely to be missed at an initial, often brief, neonatal medical examination. Clefts of the palate range from complete clefts of the hard and soft palate to submucous clefts only and may present later with feeding difficulties or failure to thrive or, in older children, with speech difficulties.

There are gender differences in the incidence of $\mathrm{CP}$ and $\mathrm{CL} / \mathrm{P}$. In this study, isolated $\mathrm{CL}, \mathrm{CP}$ and $\mathrm{CLP}$ were more in male than female $(58.59 \%$ vs. $41.41 \% ; 60.11 \%$ vs. $39.89 \%$ and $61.32 \%$ vs. $38.68 \%$ ) with total clefting $60.23 \%$ in males vs. $39.77 \%$ in females. Similarly, Blanco-Davila ${ }^{[16]}$ reported that clefts of the primary palate, either isolated or associated with secondary palate, were more frequent in boys (61.7\%) compared with girls (38.3\%). An increased birth prevalence of $\mathrm{CL}$ and CLP in boys compared with girls was found in Northern Ireland ${ }^{[17]}$. Reddy et al. ${ }^{[14]}$ reported high male predominance for clefts. Male predominance for cleft lip and palate was also confirmed by the odds ratio which determined that there was a greater possibility of a male child being born with a cleft lip and palate. al-Bustan et al. $^{[11]}$ reported in Kuwait that the male to female ratio was 0.89 for $C P, 1.14$ for $C L, 1.35$ for CLP and 1.2 for all the clefts. Yazdee et al. ${ }^{[15]}$ reported that 74 of 177 cases with clefting (41.8\%) were female and $103(58.2 \%)$ were male (M/F Ratio=1.39). Their M/F ratios were 1.66 for $C P, 0.6$ for $C L$ and 1.96 for CLP. In this respect, it had been reported that $\mathrm{CP}$ is more common in females; in female fetuses the palatal shelves take a week longer to fuse than in male fetuses, leaving more time for exposure to teratogens that can cause failure of fusion ${ }^{[18]}$. Meanwhile, Kim et al. ${ }^{[19]}$ reported $\mathrm{CP}$ to have a male dominance in the Republic of Korea, although this may be related to the short time frame of the study. Others reported that boys are more likely than girls to have a cleft lip with or without cleft palate; whereas, girls are at greater risk for isolated cleft palate ${ }^{[20]}$. Female dominance, however, has been identified both elsewhere in the U.K. and worldwide, as confirmed in Boliviaa ${ }^{[13]}$, U.S.A. ${ }^{[5]}$, Faroe Islands, Greenland and Denmark ${ }^{[21]}$, Australia ${ }^{[20]}$, Jordan ${ }^{[22]}$, and Pakistan ${ }^{[23]}$. Two studies have, however, reported an even distribution of $C L$ between the sexes ${ }^{[5,24]}$, while in Iran, $\mathrm{CL}$ has been reported as more common in girls ${ }^{[25]}$. Meanwhile, Jaruratanasirikul et al. ${ }^{[10]}$ reported that girls were slightly more common than boys, with a boy to girl ratio of 0.8:1. The higher girl to boy ratio in their study compared with other reports could be explained by the fact that the patients who were referred for secondary reconstruction were mostly girls. If the referred patients are excluded, the boy to girl ratio becomes 1.7:1. In the Gregg et al. ${ }^{[17]}$ population-based 20-year study in Northern Ireland, there was no sex dominance of CP. This finding differs from that reported previously for the region over a 10-year period when female dominance was noted ${ }^{[26]}$.

In this study, unilateral clefting was $85.61 \%$ while bilateral clefting was $14.49 \%$. Most of clefting reported in this study was left side $(55.68 \%)$ then right side (29.92\%) and lastly midline (14.39\%). In this respect, most studies give a ratio between unilateral and bilateral cleft lips to be predominantly favoring unilateral cleft lips ${ }^{[16,27]}$. Reddy et al. ${ }^{[14]}$ found $79 \%$ of the cleft lip defects were unilateral in nature. It is also widely accepted that left-sided unilateral clefts are more common than right-sided unilateral cleft lips ${ }^{[16,28,29]}$ which is supported by this study. While the mechanism is unclear, the observation that the facial artery develops slower on the left may be a factor ${ }^{[30]}$.

A number of causative factors are related to the etiology of $\mathrm{CL} / \mathrm{P}$ and $\mathrm{CP}$, including genetics, teratogen exposure, environmental factors, and maternal and paternal age. Despite the number of identifiable contributing factors, etiology of most clefts is multifactorial, complex, and remains to be completely delineated ${ }^{[18]}$. In this study, of all clefting, maternal risk factors was mostly smoking $(4.55 \%)$, followed by positive family history (3.60\%), drugs intake during pregnancy $(2.08 \%)$, infection during pregnancy (2.08\%), diet deficiency (1.52\%), and maternal diseases (1.14\%). Other studies that found a prevalence of oral cleft in family members ranging from $20 \%$ to $42 \%{ }^{[3]}$. Jaruratanasirikul et al. ${ }^{[10]}$ reported that of total 153 patients, 27 (17.7\%) had a family history of CL/P. Many environmental factors have been investigated in epidemiologic studies. Maternal smoking during pregnancy has been linked consistently with increased risk of both cleft lip with or without cleft palate and isolated cleft palate, with a population-attributable risk as high as $20 \%{ }^{[32]}$. Secondhand smoke exposure does not seem to increase risk $^{[32]}$. DeRoo et al. ${ }^{[33]}$ suggested that maternal smoking during pregnancy was associated with a small, but not statistically significant, increase in estimated relative risk for each of the cleft malformation categories. Despite numerous studies, the teratogenic effects of tobacco use in cleft formation are still debated. Using the Swedish health registry data on a large series of oral cleft cases, Kallen ${ }^{[34]}$ reported statistically significant relative risks of 1.2 and 1.3 for infant's $C L \pm C P$ and $C P$ 
respectively, among women who smoked prenatally compared to those who did not. A meta-analysis of 11 case control and cohort studies also found small but statistically significant associations between maternal prenatal smoking during the first trimester and increased risk of infant's $C L \pm C P(R R=1.3 ; 95 \% \mathrm{Cl} 1.2$, 1.4) and $\mathrm{CP}(\mathrm{RR}=1.3 ; 95 \% \mathrm{Cl} 1.1,1.6)^{[35]}$. Meta-analysis strongly supports an overall odds ratio (OR) for having CLP of $\sim 1.3$ among offspring of mothers who smoke. Increased risks from exposure to maternal smoking during the peri-conceptual period raises the possibility that genes in certain metabolic pathways may play a role in the development of CLP. Specifically, markers in the glutathione S-transferase theta (GSTT1) or nitric oxide synthase 3 (NOS3) genes appear to influence risk of $\mathrm{CL} / \mathrm{P}$ in the presence of maternal smoking. The GSTT1 markers are gene deletion variants, which suggest deficiencies in detoxification pathways may underlie some of this susceptibility. Smoking has also been recently associated with a joint risk with variants in the IRF6 gene ${ }^{[36]}$. These findings provide evidence that gene-environment interactions are important in CLP. A meta-analysis showed that maternal age $>40$ years increased risk of CLP by $56 \%$ compared to maternal age between 20 and 29 years ${ }^{[37]}$. Folate supplementation in early pregnancy has been found to reduce risk by one third ${ }^{[38]}$ to three quarters ${ }^{[39]}$, although not all studies have reported statistical significance ${ }^{[40]}$. According to some authors, infectious diseases in the mother are also capable of increasing the incidence of congenital malformations. Viruses and bacteria, to a lesser degree, may traverse the placenta and reach embryonic tissue $^{[41]}$. Blanco-Davila ${ }^{[16]}$ reported that urinary tract infection occurred in $6.4 \%$ of the mothers that had a child with cleft lip and palate and family history of such malformation was found in $11.4 \%$ of patients. This supports the multifactor hereditary character of the disease. In most studies, maternal use of multivitamin supplements in early pregnancy has been linked to decreased risk of orofacial clefts; in a meta-analysis ${ }^{[42]}$, multivitamin use was associated with a $25 \%$ reduction in birth prevalence of orofacial clefts. Potential teratogens that have been reported include retinoic acid, phenytoin, and valproic acid ${ }^{[43]}$. Other proposed risk factors include various occupational and chemical exposures, hyperthermia, stress, maternal obesity, oral hormone supplementation, ionizing radiation ${ }^{[28]}$. The complex interplay between genetic and environmental factors undoubtedly play a role in the pathogenesis of CLP. Investigation of these interactions may open new avenues of research for prevention and management of CLP.
Children with orofacial clefting face a wide variety of medical issues and medical complications. These extend beyond the surgical correction of the congenital defect, and therefore require evaluation and interventions by a wide variety of specialists. These issues are not static, as different issues manifest or become more important at different ages. For example, in the newborn period, making sure the infant can feed adequately is the primary concern, but later, orthodontic and cosmetic issues become more prominent. Other potential complications include hearing loss, speech, dental, and orthodontic complications. These require consistent monitoring through adolescence and into adulthood. In this study, the most common pediatrics complication with clefting was dental problems $(75.00 \%)$ and speech abnormalities $(75.00 \%)$, followed by feeding problems (74.62\%), anemia $(6.06 \%)$, otitis media $(5.11 \%)$, recurrent chest infection (1.52\%), hearing abnormalities (0.95\%) and airway obstruction $(0.76 \%)$. It should be noted that there are many factors, particularly in this group of subjects, which may have contributed to the early speech problems and to some degree the final speech results. The presence of oronasal fistulae situated in the alveolar process and anterior part of the hard palate were found to influence speech ${ }^{[44]}$. Enemark et al. ${ }^{[45]}$ reported that $43 \%$ of patients with unilateral cleft lip and palate had an oronasal alveolar fistula causing anterior speech distortions. Otitis media with middle ear effusion is present in virtually all infants under 2 years of age with an unrepaired CP. This is attributed to eustachian tube dysfunction. Although anatomically patent, they are unable to open properly and ventilate the middle car. Following CP repair, rates of otitis media are reduced, but for most patients, middle ear disease remains an important problem well into adult life. If untreated, chronic middle ear disease can extend to the inner ear resulting in sensorineural hearing loss ${ }^{[46]}$.

The repair of cleft palates ideally involves an interdisciplinary team encompassing a variety of specialties and fields, including otolaryngologists, oral maxillofacial surgeons, plastic surgeons, pediatricians, speech pathologists, audiologists, social workers, geneticists, and psychologists ${ }^{[18]}$. Goals of repair include restoring functional speech and swallowing, improving aesthetics and facial symmetry, and restoring competence of the velopharyngeal apparatus. In this study, age of lip and palate repair was mostly during 1-6 months followed by $>6-12$ months and then > 12 month. Preoperative infection occurred in 9 cases (1.70\%), of them $5(2.66 \%)$ in CP and $4(1.89 \%)$ in CLP. 
There is controversy related to the optimal timing of cleft palate repair, with varying recommendations, depending on which outcome is being considered ${ }^{[47]}$. Goals of palatoplasty include the separation of the nasal cavity from the oral cavity, creation of a competent velopharyngeal valve for both speech and swallowing, and preservation of midface growth ${ }^{[3]}$. For optimal speech development, recommendations for palatoplasty are as early as 3 to 6 months but at least before 12 months, when language acquisition begins ${ }^{[4]]}$. In contrast, with regard to optimal midface growth, recommendations vary as late as 2 to 15 years, as completion of transverse midface growth is thought not to occur until 5 years of age. These two goals are somewhat at odds, and have led many surgeons to perform palatoplasty between 12 and 24 months ${ }^{[47]}$. Optimizing the first early surgery for infants with clefts of the lip and palate will improve physical outcomes and reduce the barrier to social integration confronted in later life.

Most of our cases made one operation ( $\mathrm{n}=309$, $58.52 \%)$, while 205 cases $(38.83 \%)$ made 2 repair operations and 14 cases (2.65\%) made 3 repair operations. A UK national study has shown that the need for secondary corrective surgery can be 10 times higher when primary surgery is unsuccessful[48]. Identifying optimal methods of the primary surgery will reduce hospital visits during childhood and adolescence and avoid wastage of Health Services resources on outpatient therapy.

The long-term health concerns for CLP patients, as well as for children with birth defects in general, have been insufficiently studied. In this study, most cases of clefting received antibiotics [522 (98.86\%) cases]. It is reasonable to assume that individuals with CLP should have relatively normal long-term health, as CLP is a repairable birth defect, and the associated medical issues are for the most part readily treatable ${ }^{[49]}$. However, several studies have suggested that individuals with CLP have a higher than expected incidence of psychiatric and behavioral diseases ${ }^{[50]}$, an increased risk for cancer ${ }^{[51]}$, and an increased mortality in general from all major causes of death ${ }^{[49]}$.

Postoperative complications reported in our cases were mostly speech abnormalities (72.54\%) followed by fever $(6.82 \%)$, otitis media (3.41\%), fistula $(1.70 \%)$, chest infection $(1.14 \%)$, bleeding $(1.14 \%)$, hearing problems $(0.76 \%)$, airway obstruction $(0.38 \%)$, and wound complications $(0.38 \%)$. Length of hospital stay was 1-2 days in $\mathrm{CL}(100.00 \%)$ and 3-4 days in CP (100.00\%) and CLP (100.00\%). Postoperative bleeding is a rare complication and blood loss during surgery is generally minimal at 50 to $60 \mathrm{~mL}^{[3]}$. Following surgery, recovery can be complicated by development of oronasal fistula with reports ranging from $8.7 \%$ to $23 \%$, though this varies with severity of clefting, type of cleft, and technique used. Patients with clefts of the hard and soft palate, and those with submucous cleft palate (SMCP), are more likely to develop fistulas than those with clefts of the soft palate alone ${ }^{[52]}$. Common sites of fistulas are the anterior hard palate and the junction of the hard and soft palate ${ }^{[3]}$. The most common complication after $\mathrm{CP}$ repair is velopharyngeal insufficiency (VPI), the rate of which may reach as high as 25 to $30 \%{ }^{[53]}$. Velopharyngeal insufficiency has an effect on both speech and swallowing, causing hypernasal speech, and nasal regurgitation with swallowing as the degree of opening and closure of the velopharyngeal sphincter is an important component of producing specific consonant sounds ${ }^{[54]}$. While these findings must be viewed as preliminary, they emphasize the need for more comprehensive and extended follow-up of CLP patients to monitor for these and other longterm healthcare complications.

\section{Conclusion}

Cleft lip and palate (CLP) was more common in this group then isolated $\mathrm{CP}$ and $\mathrm{CL}$, a result different from some previous studies. This may represent underreporting of this particular cleft type or etiological differences and requires further study. Boys were affected more often than girls and unilateral left side was more common than bilateral and unilateral right side. Of all clefting, maternal risk factor was mostly positive smoking, and pediatrics complication was mostly feeding problems. Postoperative complications were mostly speech abnormalities. We believe that there is no one isolated factor determining the occurrence of clefts, and we support the multifactor etiology of this malformation as do most international researchers in epidemiologic studies of their region. Routine screening such as chest X-ray and ruling out hearing and speech problems as well as genetic counseling and karyotyping may be necessary in these patients. Better understanding of demographic and clinical characteristics may help guide clinical care as well as contribute to an improved understanding of pathogenesis. 


\section{Conflict of Interest}

The authors have no conflict of interest.

\section{Disclosure}

None of the authors received any type of commercial support either in forms of compensation or financial for this study. They have no financial interest in any of the products or devices, or drugs mentioned in this article.

\section{Ethical Approval}

Obtained.

\section{References}

[1] Cooper ME, Ratay JS, Marazita ML. Asian oral-facial cleft birth prevalence. Cleft Palate Craniofac J 2006; 43(5): 580589.

[2] Parker SE, Mai CT, Canfield MA, Rickard R, Wang Y, Meyer RE, Anderson P, Mason CA, Collins JS, Kirby RS, Correa A; National Birth Defects Prevention Network. Updated National Birth Prevalence estimates for selected birth defects in the United States, 2004-2006. Birth Defects Res A Clin Mil Teratol 2010; 88(12): 1008-1016.

[3] Friedman O, Wang TD, Milczuk HA. Cleft lip and palate. In: Cummings Otolaryngology Head \& Neck Surgery. Flint PW, Haughey BH, Lund VJ, eds. Philadelphia, PA: Mosby Elsevier, 2010. 2659-2675.

[4] Wehby G, Cassell CH. The impact of orofacial clefts on quality of life and healthcare use and costs. Oral Dis 2010; 16(1): 3-10.

[5] Shapira Y, Lubit E, Kuftinec MM, Borell G. The distribution of clefts of the primary and secondary palates by sex, type, and location. Angle Orthod 1999; 69(6): 523-528.

[6] Lorente C, Cordier S, Goujard J, Aymé S, Bianchi F, Calzolari E, De Walle HE, Knill-Jones R. Tobacco and alcohol use during pregnancy and risk of oral clefts. Occupational Exposure and Congenital Malformation Working Group. Am J Public Health 2000; 90(3): 415-419.

[7] Werler MM, Lammer EJ, Rosenberg L, Mitchell AA. Maternal alcohol use in relation to selected birth defects. Am J Epidemiol 1991; 134(7): 691-698.

[8] Werler MM, Hayes C, Louik C, Shapiro S, Mitchell AA. Multivitamin supplementation and risk of birth defects. Am J Epidemiol 1999; 150 (7): 675-682.

[9] Zucchero TM, Cooper ME, Maher BS, Daack-Hirsch S, Nepomuceno B, Ribeiro L, Caprau D, Christensen K, Suzuki Y, Machida J, Natsume N, Yoshiura K, Vieira AR, Orioli IM, Castilla EE, Moreno L, Arcos-Burgos M, Lidral AC, Field LL, Liu YE, Ray A, Goldstein TH, Schultz RE, Shi M, Johnson MK, Kondo S, Schutte BC, Marazita ML, Murray JC. Interferon regulatory factor 6 (IRF6) gene variants and the risk of isolated cleft lip or palate. N Engl J Med 2004; 351(8): 769_ 780.

[10] Jaruratanasirikul S, Chichareon V, Pattanapreechawong N, Sangsupavanich P. Lip and/or palate: 10 years' experience at a pediatric cleft center in Southern Thailand. Cleft Palate Craniofac J 2008; 45(6): 597-602.

[11] al-Bustan SA, el-Zawahri MM, al-Adsani AM, Bang RL, Ghunaim I, Maher BS, Weinberg S, Marazita ML. Epidemiological and genetic study of 121 cases of oral clefts in Kuwait. Orthod Craniofac Res 2002; 5(3): 154-160.

[12] Croen LA, Shaw GM, Wasserman CR, Tolarová MM. Racial and ethnic variations in the prevalence of orofacial clefts in California 1983-1992. Am J Med Genet 1998; 79(1): 42-47.

[13] McLeod NM, Urioste ML, Saeed NR. Birth prevalence of cleft lip and palate in Sucre, Bolivia. Cleft Palate Craniofac J 2004; 41(2): 195-198.

[14] Reddy SG, Reddy RR, Bronkhorst EM, Prasad R, Ettema AM, Sailer HF, Bergé SJ. Incidence of cleft lip and palate in the state of Andhra Pradesh, South India. Indian J Plast Surg 2010; 43(2): 185-189.

[15] Yazdee AK, Saedi B, Sazegar AA, Mehdipour P. Epidemiological aspects of cleft lip and palate in Iran. Acta Med Iran 2011; 49(1): 54-58.

[16] Blanco-Davila F. Incidence of cleft lip and palate in the northeast of Mexico: a 10-year study. J Craniofac Surg 2003; 14(4): 533-537.

[17] Gregg TA, Leonard AG, Hayden C, Howard KE, Coyle CF. Birth prevalence of cleft lip and palate in Northern Ireland (1981 to 2000). Cleft Palate Craniofac J 2008; 45(2): 141147.

[18] Marazita ML, Mooney MP. Current concepts in the embryology and genetics of cleft lip and cleft palate. Clin Plast Surg 2004; 31(2): 125-140.

[19] Kim S, Kim WJ, Oh C, Kim JC. Cleft lip and palate incidence among the live births in the Republic of Korea. J Korean Med Sci 2002; 17(1): 49-52.

[20] Vallino-Napoli LD, Riley MM, Halliday J. An epidemiologic study of isolated cleft lip, palate, or both in Victoria, Australia from 1983-2000. Cleft Palate Craniofac J 2004; 41(2): 185-194.

[21] Jakobsen LP, Mølsted K, Christensen K. Occurrence of cleft lip and palate in the Faroe Islands and Greenland from 1950 to 1999. Cleft Palate Craniofac J 2003; 40(4): 426-430.

[22] Al-Omari F, Al-Omari IK. Cleft lip and palate in jordan: birth prevalence rate. Cleft Palate Craniofac J 2004; 41(6): 609_ 612.

[23] Elahi MM, Jackson IT, Elahi O, Khan AH, Mubarak F, Tariq GB, Mitra A. Epidemiology of cleft lip and palate in Pakistan. Plast Reconstr Surg 2004; 113(6): 1548-1555.

[24] Hewson AR, McNamara CM. Cleft lip and/or palate in the West of Ireland, 1980-1996. Spec Care Dentist 2000; 20(4): 143-146.

[25] Rajabian MH, Sherkat M. An epidemiologic study of oral 
clefts in Iran: analysis of 1669 cases. Cleft Palate Craniofac J 2000; 37(2): 191-196.

[26] Gregg T, Boyd D, Richardson A. The incidence of cleft lip and palate in Northern Ireland from 1980-1990. Br J Orthod 1994; 21(4): 387-392.

[27] Jensen BL, Kreiborg S, Dahl E, Fogh-Andersen P. Cleft lip and palate in Denmark, 1976-1981: Epidemiological, variability, and early somatic development. Cleft Palate J 1988; 25(3): 258-269.

[28] Dixon MJ, Marazita ML, Beaty TH, Murray JC. Cleft lip and palate: synthesizing genetic and environmental influences. Nat Rev Genet 2011; 12(3): 167-178.

[29] Lithovius RH, Ylikontiola LP, Harila V, Sándor GK. A descriptive epidemiology study of cleft lip and palate in Northern Finland. Acta Odontol Scand 2014; 72(5): 372-375.

[30] Hirayama K. Anatomical studies on the development of the facial artery and its distribution in the cleft lip of the human fetus. Part 1 development of the facial artery in the human fetus on the latter stage of pregnancy. Med J Kagoshima Univ 1971; 1: 295-316.

[31] Chuangsuwanich A, Aojanepong C, Muangsombut S, Tongpiew P. Epidemiology of cleft lip and palate in Thailand. Ann Plast Surg 1998; 41(1): 7-10.

[32] Honein MA, Rasmussen SA, Reefhuis J, Romitti PA, Lammer EJ, Sun L, Correa A. Maternal smoking and environmental tobacco smoke exposure and the risk of orofacial clefts. Epidemiology 2007; 18(2): 226-233.

[33] DeRoo LA, Gaudino JA, Edmonds LD. Orofacial cleft malformations: associations with maternal and infant characteristics in Washington State. Birth Defects Res A Clin Mol Teratol 2003; 67(9): 637-642.

[34] Kallen K. Maternal smoking and orofacial clefts. Cleft Palate Craniofac J 1997; 34(1): 11-16.

[35] Wyszynski DF, Duffy DL, Beaty TH. Maternal cigarette smoking and oral clefts: a meta-analysis. Cleft Palate Craniofac J 1997; 34(3): 206-210.

[36] Wu T, Liang KY, Hetmanski JB, Ruczinski I, Fallin MD, Ingersoll RG, Wang H, Huang $S$, Ye $X$, Wu-Chou $Y H$, Chen PK, Jabs EW, Shi B, Redett R, Scott AF, Beaty TH. Evidence of gene environment interaction for the IRF6 gene and maternal multivitamin supplementation in controlling the risk of cleft lip with/without cleft palate. Hum Genet 2010; 128(4): 401-410.

[37] Herkrath AP, Herkrath FJ, Rebelo MA, Vettore MV. Parental age as a risk factor for non-syndromic oral clefts: a metaanalysis. J Dent 2012; 40(1): 3-14.

[38] Wilcox AJ, Lie RT, Solvoll K, Taylor J, McConnaughey DR, Abyholm F, Vindenes H, Vollset SE, Drevon CA.. Folic acid supplements and risk of facial clefts: national population based case control study. BMJ 2007; 334(7591): 464.

[39] Kelly D, O'DowdT, Reulbach U. Use of folic acid supplements and risk of cleft lip and palate in infants: a population-based cohort study. Br J Gen Pract 2012; 62(600): e466-472.
[40] Wehby GL, Ohsfeldt RL, Murray JC. 'Mendelian randomization' equals instrumental variable analysis with genetic instruments. Stat Med 2008; 27(15): 2745-2749.

[41] Trigos I, Saavedra-Ontiveros M. [Cirugía plástica reconstructive y estética]. 2nd ed, vol II. Bogota, Colombia: Masson-Salvat, 1994; 1519-1532

[42] Johnson CY, Little J. Folate intake, markers of folate status and oral clefts: is the evidence converging? Int J Epidemiol 2008; 37(5): 1041-1058.

[43] Jentink J, Loane MA, Dolk H, Barisic I, Garne E, Morris JK, de Jong-van den Berg LT; EUROCAT Antiepileptic Study Working Group. Valproic acid monotherapy in pregnancy and major congenital malformations. N Engl J Med 2010; 362(23): 2185-2193.

[44] Shelton RL, Blank JL. Oronasal fistulas, interoral air pressure, and nasal air flow during speech. Cleft Palate J 1984; 21(2): 91-99.

[45] Enemark H, Simonsen EK, Schramm JE. Secondary bone grafting in unilateral cleft lip and palate patients: indications and treatment procedure. Int J Oral Surg 1985; 14(1): 2-10.

[46] [No authors listed]. Parameters for Evaluation and Treatment of Patients with Cleft Lip/ Palate or Other Craniofacial Anomalies. American Cleft Palate-Craniofacial Association. Cleft Palate-Craniofacial Journal 1993; 30 (Suppl 1). Revised April 2000. Available at <http://www.cleftline.org/>.

[47] Leow AM, Lo LJ. Palatoplasty: evolution and controversies. Chang Gung Med J 2008; 31(4): 335-345

[48] Bearn D, Mildinhall S, Murphy T, Murray JJ, Sell D, Shaw WC, Williams AC, Sandy JR. Cleft lip and palate care in the United Kingdom--the Clinical Standards Advisory Group (CSAG) Study. Part 4: outcome comparisons, training, and conclusions. Cleft Palate Craniofac J 2001; 38(1): 38-43.

[49] Christensen K, Juel K, Hersking AM, Murray JC. Long term follow-up study of survival associated with cleft lip and palate at birth. BMJ 2004; 328(7453): 1405-1407.

[50] Christensen K, Mortensen PB. Facial clefting and psychiatric diseases: a follow-up of the Danish 1936-1987 Facial Cleft cohort. Cleft Palate Craniofac J 2002; 39(4): 392-396.

[51] Zhu JL, Basso O, Hasle H, Winther JF, Olsen JH, Olsen J. Do parents of children with congenital malformations have a higher cancer risk? A nationwide study in Denmark. Br J Cancer 2002: 87(5): 524-528.

[52] Andersson EM, Sandvik L, Semb G, Abyholm F. Palatal fistulas after primary repair of clefts of the secondary palate. Scand J Plast Reconstruct Surg Hand Surg 2008; 42(6): 296-299.

[53] Phua YS, de Chalain T. Incidence of oronasal fistulae and velopharyngeal insufficiency after cleft palate repair: an audit of 211 children born between 1990 and 2004. Cleft Palate Craniofac J 2008; 45(2): 172-178.

[54] Hopper RA, Tse R, Smartt J, Swanson J, Kinter S. Cleft palate repair and velopharyngeal dysfunction. Plast Reconstruct Surg 2014; 133(6): 852e-864e. 


\section{أشواه الفلوح الفموية الوجهية غير المتلازمية في جدة، المملكة العربية

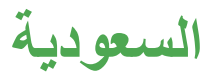

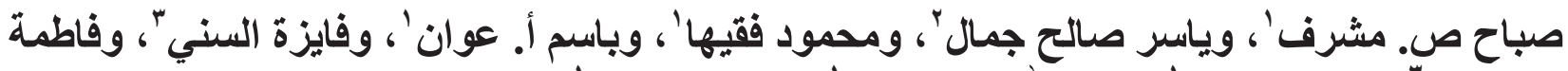

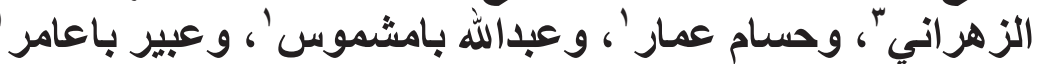

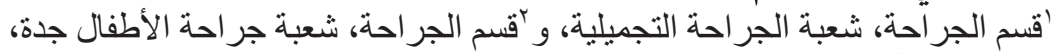

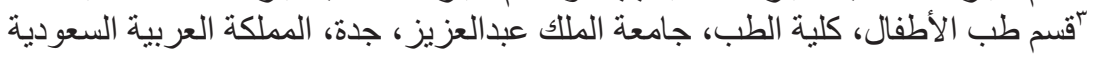

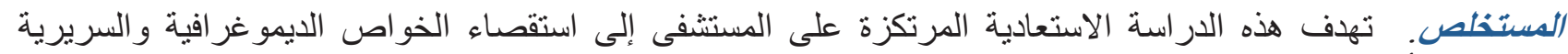

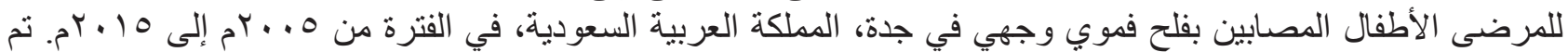

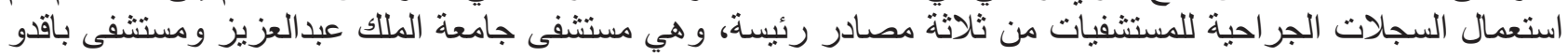

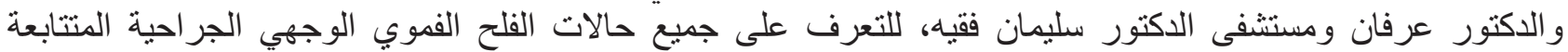

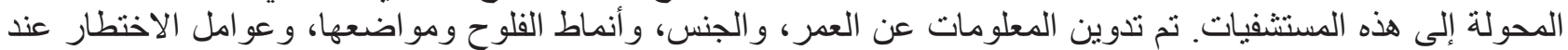

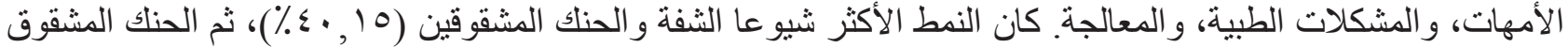

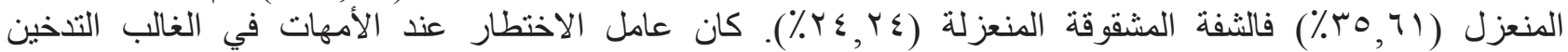

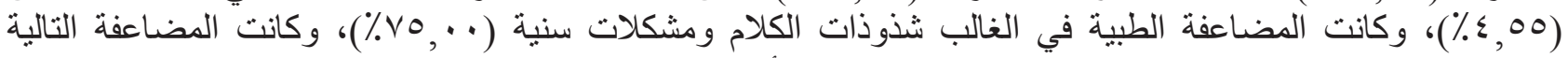

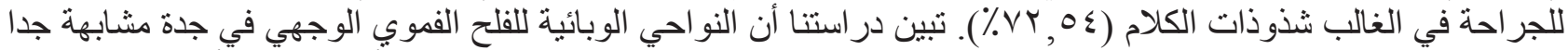

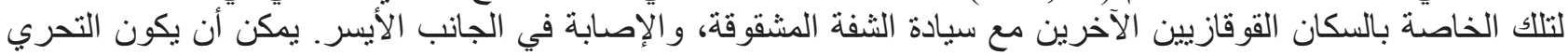

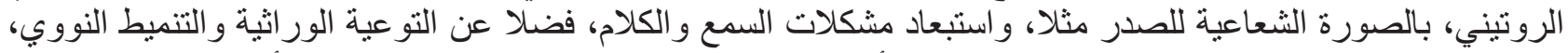

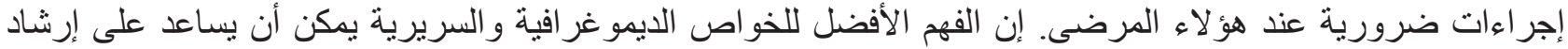

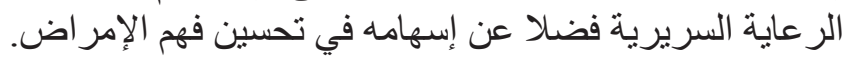

